\title{
Weight reduction and the impaired plasma-derived free fatty acid oxidation in type 2 diabetic subjects
}

Citation for published version (APA):

Blaak, E. E., Wolffenbuttel, B. H. R., Saris, W. H. M., Pelsers, M. M. A. L., \& Wagenmakers, A. J. M. (2001). Weight reduction and the impaired plasma-derived free fatty acid oxidation in type 2 diabetic subjects. Journal of Clinical Endocrinology \& Metabolism, 86, 1638-1644.

https://doi.org/10.1210/jc.86.4.1638

Document status and date:

Published: 01/01/2001

DOI:

10.1210/jc.86.4.1638

Document Version:

Publisher's PDF, also known as Version of record

Please check the document version of this publication:

- A submitted manuscript is the version of the article upon submission and before peer-review. There can be important differences between the submitted version and the official published version of record.

People interested in the research are advised to contact the author for the final version of the publication, or visit the DOI to the publisher's website.

- The final author version and the galley proof are versions of the publication after peer review.

- The final published version features the final layout of the paper including the volume, issue and page numbers.

Link to publication

\footnotetext{
General rights rights.

- You may freely distribute the URL identifying the publication in the public portal. please follow below link for the End User Agreement:

www.umlib.nl/taverne-license

Take down policy

If you believe that this document breaches copyright please contact us at:

repository@maastrichtuniversity.nl

providing details and we will investigate your claim.
}

Copyright and moral rights for the publications made accessible in the public portal are retained by the authors and/or other copyright owners and it is a condition of accessing publications that users recognise and abide by the legal requirements associated with these

- Users may download and print one copy of any publication from the public portal for the purpose of private study or research.

- You may not further distribute the material or use it for any profit-making activity or commercial gain

If the publication is distributed under the terms of Article $25 \mathrm{fa}$ of the Dutch Copyright Act, indicated by the "Taverne" license above 


\title{
Weight Reduction and the Impaired Plasma-Derived Free Fatty Acid Oxidation in Type 2 Diabetic Subjects*
}

\author{
E. E. BLAAK, B. H. R. WOLFFENBUTTEL, W. H. M. SARIS, M. M. A. L. PELSERS, \\ AND A. J. M. WAGENMAKERS
}

Departments of Human Biology, Endocrinology (B.H.R.W.), and Physiology (M.M.A.L.P.), Nutrition Research Center, Maastricht University, 6200 MD Maastricht, The Netherlands

\begin{abstract}
In a previous study the oxidation of plasma free fatty acids (FFA) under baseline conditions and during exercise was lower in type 2 diabetic subjects compared with weight-matched controls. The present study intended to investigate the effect of weight reduction (very low calorie diet) on plasma FFA oxidation in seven type 2 diabetic male subjects (body fat, $37.4 \pm 1.2 \%$; age, $51.3 \pm 3.4 \mathrm{yr}$; plasma glucose, $7.45 \pm 0.48 \mathrm{mmol} / \mathrm{L})$. Subjects underwent a 10 -week diet period. Body composition and substrate utilization during rest and during bicycle exercise (50\% of maximum aerobic capacity) were determined before and after the diet (during weight-stable conditions). FFA metabolism was studied by means of the tracer $\left[\mathrm{U}^{13} \mathrm{C}\right]$ palmitate. Rates of oxidation of plasma FFA were corrected with an acetate recovery factor. Additionally, activities of mitochondrial enzymes and cytosolic fatty acid-binding protein were determined in biopsies from the vastus lateralis muscle before and after the diet.
\end{abstract}

The very low calorie diet resulted in a weight loss of $15.3 \mathrm{~kg}$ $(110.8 \pm 7.4 v s .95 .5 \pm 5.8 \mathrm{~kg} ; P<0.01)$. The basal rates of appearance and disappearance of FFA decreased as a result of diet. The rates of appearance and disappearance of FFA during exercise were not different before and after diet. The oxidation of plasma-derived fatty acids tended to decrease after diet during baseline conditions $(P=$ 0.10 ), whereas the plasma FFA oxidation during exercise was not different before and after the diet $(14.1 \pm 1.9 \mathrm{vs} .14 .8 \pm 1.8 \mu \mathrm{mol} / \mathrm{kg}$ fat-free mass'min). Skeletal muscle cytosolic fatty acid-binding protein and the activities of muscle oxidative enzymes did not significantly change as a result of weight loss.

In conclusion, considerable weight reduction did not significantly improve plasma-derived FFA oxidation under baseline conditions and during exercise, suggesting that this impairment reflects a primary defect leading to the development of type 2 diabetes mellitus rather than resulting from the type 2 diabetic state. ( $J$ Clin Endocrinol Metab 86: 1638-1644, 2001)
$\mathrm{D}$ ISTURBANCES IN FATTY acid (FFA) utilization play an important role in the etiology of insulin resistance and type 2 diabetes mellitus. The uptake and oxidation of FFA were diminished in skeletal muscle of type 2 diabetic subjects during postabsorptive conditions, during $\beta$-adrenergic stimulation $(1,2)$, and during exercise (3).

A diminished uptake of FFA by skeletal muscle in type 2 diabetic subjects may increase circulating FFA concentrations and FFA supply to the liver, resulting in decreased insulin binding to hepatocytes (4), diminished hepatic insulin clearance, impaired insulin-mediated suppression of hepatic glucose output (5), and increased very low density lipoprotein-triglyceride output (6). Additionally, an impaired relationship between FFA uptake and oxidation may increase im triglyceride storage, which is an important marker of skeletal muscle insulin resistance (7).

Several mechanisms may be responsible for this impaired ability of skeletal muscle to take up or oxidize plasma fatty acids. In a previous study we showed a lowered rate of appearance of FFA (RaFFA) in type 2 diabetic subjects both under baseline conditions as well as during physical exercise

Received August 15, 2000. Revision received December 1, 2000. Accepted December 6, 2000

Address all correspondence and requests for reprints to: Dr. E. E. Blaak, Department of Human Biology, Nutrition Research Center, Maastricht University, P.O. Box 616, 6200 MD Maastricht, The Netherlands. E-mail: e.blaak@hb.unimaas.nl.

* This work was supported by a grant from the Dutch Diabetes Research Foundation and The Netherlands Organization for Scientific Research
(3), suggesting that a diminished FFA availability may contribute to the impaired disposal and oxidation of fatty acids. Secondly, there are indications that muscle lipolysis may be increased in type 2 diabetic subjects. An increased muscle lipolysis may flood the muscle with FFA, thereby decreasing the blood-tissue concentration gradient, which is one of the primary determinants of plasma fatty acid uptake and oxidation (8). Thirdly, there are several biochemical determinants for the capacity to use fatty acids in skeletal muscle of type 2 diabetic subjects, such as fiber type (9), a lowered oxidative enzyme capacity (2), the activity of carnitine palmitoyl transferase (10), and a lowered pattern of expression of various fatty acid-binding proteins (11).

To date, it is not known whether impairments in the pathways of FFA utilization in skeletal muscle are primary defects or arise secondarily as a result of the diabetic state. Impairments in the ability of the skeletal muscle to use FFA have also been reported in obese subjects during postabsorptive conditions (12) and $\beta$-adrenergic stimulation (13), suggesting that an impaired capacity to use fat may be one of the factors linking obesity to type 2 diabetes mellitus by promoting skeletal muscle insulin resistance and hyperglycemia. Additionally, persistent impairments in FFA utilization have been previously reported after weight loss in obese subjects $(14,15)$, suggesting that these defects could also be primary to the obese state. This is consistent with the findings that a decreased reliance on lipid oxidation is a risk factor for weight gain (16) and for weight regain after weight loss (17).

In a recent study we found lowered plasma-derived FFA 
oxidation in type 2 diabetic subjects compared with controls matched for age, body composition, and maximal aerobic capacity under baseline conditions and during exercise (3). To obtain more insight into the roles of these impairments in the etiology of type 2 diabetes mellitus, the previously studied diabetic subjects were restudied after a period of weight reduction. Additionally, muscle biopsies from the vastus lateralis were taken to determine the changes in cytosolic fatty acid-binding protein and indicators of $\beta$-oxidation and general oxidative capacity, which previously appeared to be lowered in type 2 diabetic subjects (2).

\section{Subjects and Methods}

Seven male subjects with type 2 diabetes mellitus were studied (age, $51.3 \pm 3.4 \mathrm{yr})$. The subjects were treated with diet alone $(\mathrm{n}=2)$ or with diet together with sulfonylureas $(n=5)$. Blood glucose-lowering medication was stopped 2 days before the experiments and was not resumed during the entire diet period and after diet measurements. No other medication was used. None of the subjects had serious health problems apart from diabetes. A normal resting electrocardiogram was a prerequisite for participation. The subjects' characteristics are indicated in Table 1. All subjects engaged in sports for no more than $3 \mathrm{~h}$ a week, and none had a physically demanding job. The study protocol was approved by the medical ethical review committee of Maastricht University. Informed written consent was obtained from all subjects.

\section{Experimental design}

Before and after the diet period, measurements were made of body composition, maximal aerobic power, insulin sensitivity, markers of FFA transport and oxidation in muscle biopsies, and FFA kinetics. For determining FFA kinetics during exercise, all subjects participated in two stable isotope experiments in random order. In one study whole body fatty acid metabolism was studied during baseline conditions and during 1-h cycling exercise at $50 \%$ of the predetermined maximum aerobic capacity $\left(\mathrm{VO}_{2} \max \right)$ during continuous iv infusion of the stable isotope tracer $\left[\mathrm{U}-{ }^{13} \mathrm{C}\right]$ palmitate (protocol 1). The fraction of ${ }^{13} \mathrm{CO}_{2}$ recovered in breath during iv infusion of the stable isotope tracer $\left[1,2-{ }^{13} \mathrm{C}\right]$ acetate (acetate recovery factor) was determined in a separate experiment (protocol 2). This acetate recovery factor was used to correct tracer estimations of plasma fatty acid oxidation during $\left[\mathrm{U}-{ }^{13} \mathrm{C}\right]$ palmitate infusion for label fixation into products of the citric acid cycle and in the bicarbonate pool and has previously been extensively validated $(18-20)$.

\section{Diet period}

The total diet intervention period lasted 10 weeks. During the first 4 weeks of the diet period the subjects followed a very low calorie diet (Modifast, Novartis Nutrition, Breda, The Netherlands) of $2 \mathrm{MJ} /$ day, which

TABLE 1. Body composition, maximum aerobic capacity and work load, and insulin sensitivity before and after weight loss

\begin{tabular}{lcc}
\hline & Before & After \\
\hline Wt $(\mathrm{kg})$ & $110.8 \pm 7.1$ & $95.5 \pm 5.8^{a}$ \\
BMI $\left(\mathrm{kg} / \mathrm{m}^{2}\right)$ & $33.7 \pm 1.1$ & $29.1 \pm 1.1^{a}$ \\
$\%$ Body fat & $37.4 \pm 1.2$ & $31.2 \pm 1.5^{a}$ \\
Fat mass $(\mathrm{kg})$ & $41.7 \pm 3.3$ & $30.0 \pm 2.7^{a}$ \\
Fat-free mass $(\mathrm{kg})$ & $69.1 \pm 4.2$ & $65.4 \pm 3.5^{a}$ \\
VO $_{2}$ max $\left(\mathrm{mL} / \mathrm{kg}_{\mathrm{FFM}} \cdot \mathrm{min}\right)$ & $36.2 \pm 2.9$ & $41.3 \pm 2.4$ \\
$\mathrm{Wmax}_{\left(\mathrm{watts} / \mathrm{kg}_{\mathrm{FFM}} \cdot \mathrm{min}\right)}$ & $2.67 \pm 0.19$ & $3.03 \pm 0.17$ \\
Fasting glucose (mmol/L) & $7.45 \pm 0.48$ & $6.46 \pm 0.59^{b}$ \\
Fasting insulin $(\mathrm{mU} / \mathrm{L})$ & $17.5 \pm 1.7$ & $11.4 \pm 1.5^{b}$ \\
KITT $(\% / \mathrm{min})^{c}$ & $2.1 \pm 0.2$ & $2.7 \pm 0.3^{b}$ \\
\hline
\end{tabular}

Values are the mean $\pm \mathrm{SE}(\mathrm{n}=7)$.

${ }^{a} P<0.001$, by paired $t$ test.

${ }^{b} P<0.05$, by paired $t$ test.

${ }^{c}$ First order constant for the disappearance rate of glucose after iv insulin provided $52 \mathrm{~g}$ /day protein, $50 \mathrm{~g} /$ day carbohydrate, $7 \mathrm{~g} /$ day fat, and 1.3 $\mathrm{g} /$ day sodium and a micronutrient content that meets the Dutch recommended daily allowances. In the fifth week subjects were allowed to replace one sachet per day with an energy-restricted meal (dinner), which was increased to two energy-restricted meals/day in week 6 . In the seventh and eighth weeks subjects consumed an energy restricted diet of $4.2 \mathrm{MJ} /$ day. During weeks 9-10 subjects were in weight-stable conditions.

\section{Body composition}

Body weight was determined on an electronic scale that was accurate to $0.1 \mathrm{~kg}$. Waist and hip circumference measurements to the nearest $1 \mathrm{~cm}$ were made with the subjects standing upright. Body composition was determined by hydrostatic weighing with simultaneous lung volume measurement (Volugraph 2000, Mijnhardt, The Netherlands). Body composition was calculated according to the method described by Siri (21).

\section{Maximum aerobic capacity}

The maximum aerobic capacity of the subjects was determined during an incremental protocol on a cycle ergometer. After two steps lasting $2.5 \mathrm{~min}$ at 0.75 and 1.5 watts $/ \mathrm{kg}$ fat-free mass (FFM), the work load was increased by 0.5 watts/ $\mathrm{kg}$ FFM every 2.5 min until exhaustion. Criteria for stopping the exercise were respiratory exchange ratio greater than 1.15 and no further increase in oxygen uptake.

\section{Insulin sensitivity}

To obtain an indication of insulin sensitivity, a short iv insulin tolerance test was performed, as reported previously (22). Subjects came to the laboratory after an overnight fast. While resting supine, two cannulas were inserted: one into an antecubital forearm vein for the administration of insulin and glucose, and the other in a dorsal hand vein for the sampling of arterialized venous blood. At least $20 \mathrm{~min}$ before the test started, the cannulated hand was placed in a warm air box, which circulated air at $60 \mathrm{C}$. After determination of the basal glucose concentration, insulin was administered in a dose of $0.1 \mathrm{U} / \mathrm{kg}$ BW. The blood glucose concentration was determined every $2 \mathrm{~min}$ for 16 min using a blood glucose analyzer (YSI, Inc., Yellow Springs, OH). Glucose was injected at $16 \mathrm{~min}$ to stop the fall in blood glucose. Insulin sensitivity was calculated from the first order constant for the disappearance rate of glucose (Kitt), estimated from the slope of the regression line of the logarithm of blood glucose against time during the first 4-16 min according to the following equation: Kitt $(\%)=\left(0.693 / t_{1 / 2}\right) \times 100 \%(22)$.

\section{Muscle biopsies}

On a separate occasion, needle muscle biopsies were taken percutaneously from the vastus lateralis muscle after an overnight fast, using the Bergström method with suction (23). The biopsies were immediately frozen in liquid nitrogen and stored at $-80 \mathrm{C}$ until determination of the activities of mitochondrial enzymes, lactate dehydrogenase and cytosolic cytosolic fatty acid-binding protein (FABPc; see Biochemical methods).

\section{Protocol 1: [U- $\left.{ }^{13} \mathrm{C}\right]$ palmitate infusion}

The subjects arrived at the laboratory after an overnight fast (of at least $12 \mathrm{~h}$ ) at $0800 \mathrm{~h}$ by car or public transport. They were studied while resting supine on a comfortable bed in a room kept at $23-25 \mathrm{C}$. At the beginning of the experiments, cannulas were inserted in a forearm vein for the infusion of the stable isotope tracer and in a dorsal hand vein of the contralateral arm for obtaining arterialized venous blood. After placement of the catheters, the hand was placed in a warm air box where air was circulated at $60 \mathrm{C}$. After taking background blood and breath samples ( $30 \mathrm{~min}$ after placement of the hand in the warm air box), an iv priming dose of $0.085 \mathrm{mg} / \mathrm{kg} \mathrm{NaH}{ }^{13} \mathrm{CO}_{3}$ was given. Then, a constant rate continuous infusion of $\left[\mathrm{U}_{-}{ }^{13} \mathrm{C}\right]$ palmitate was started $(0.008 \mu \mathrm{mol} / \mathrm{kg}$ BW·min) via a calibrated infusion pump (560 pump; IVAC, San Diego, CA). After a 2-h baseline period (0-120 $\mathrm{min})$, the rate of palmitate infusion was doubled during the 1-h cycling exercise period (121-180 $\min )$ at $50 \% \mathrm{VO}_{2} \max$. The concentration of palmitate in the infusate was measured for each experiment (see Biochemical methods), so that the exact infusion rate could be determined. The palmitate tracer $(60 \mathrm{mg}$ of the 
TABLE 2. Circulating concentrations of metabolites during baseline conditions and during a 60-min period of moderate intensity exercise before and after weight loss

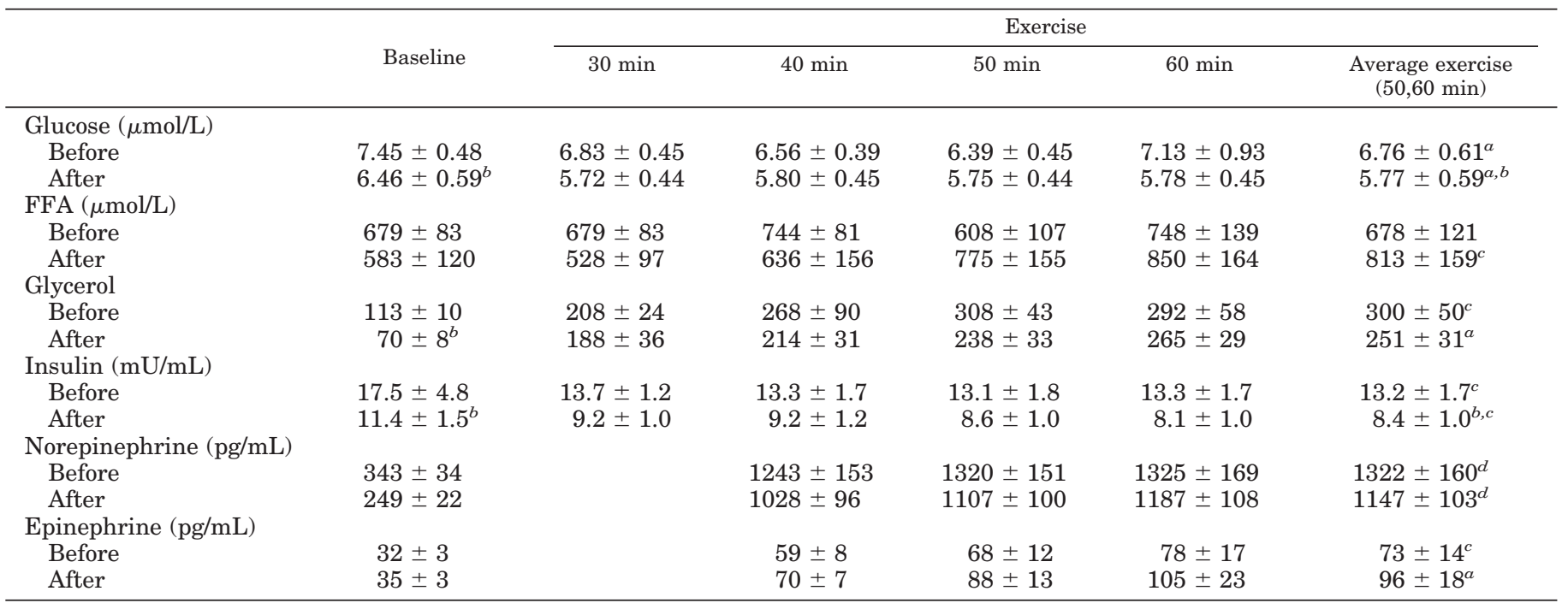

Values are the mean $\pm \mathrm{SE}(\mathrm{n}=7)$.

${ }^{a} P<0.01$, average exercise vs. baseline.

${ }^{b} P<0.05$, baseline and exercise, before $v s$. after.

${ }^{c} P<0.05$, average exercise $v s$. baseline.

${ }^{d} P<0.001$, average exercise $v s$. baseline.

potassium salt of $\left[\mathrm{U}_{-13}{ }^{13} \mathrm{C}\right]$ palmitate, $99 \%$ enriched; Cambridge Isotope Laboratories, Andover, MA) was dissolved in heated sterile water and passed through a $0.2-\mu \mathrm{m}$ pore size filter into a $5 \%$ warm human serum albumin (Central Blood Bank, Amsterdam, The Netherlands) to make a $0.65-\mathrm{mmol} / \mathrm{L}$ solution (mean $\pm \mathrm{sD}, 0.650 \pm 0.025 \mathrm{mmol} / \mathrm{L}$ ).

\section{Breath, blood, and urine sampling}

Five minutes before the start of infusion (background), and at 100, 110 , and 120 min during the baseline period and 150,160, 170, and 180 during exercise, breath samples were taken to determine the enrichment of $\mathrm{CO}_{2}\left({ }^{13} \mathrm{C} /{ }^{12} \mathrm{C}\right.$ ratio) in expired air. Expired air samples were obtained by having the subjects breathe normally for 3 min into a mouthpiece, connected to a 6.75-L mixing chamber and then collecting a breath sample into a $20-\mathrm{mL}$ Vacutainer tube. Additionally, at the above-indicated time points arterialized blood samples were taken to determine the concentrations of glucose, insulin, glycerol, $\mathrm{O}_{2}$, FFA, and palmitate as well as the ${ }^{13} \mathrm{C} /{ }^{12} \mathrm{C}$ ratio of palmitate. During the resting period and the last $40 \mathrm{~min}$ of exercise, $\mathrm{O}_{2}$ and $\mathrm{CO}_{2}$ exchanges were determined by means of an open circuit ventilated hood system (Oxycon $\beta$; Mijnhardt, The Netherlands). Urine was collected overnight in containers with 10 $\mathrm{mL} \mathrm{H}_{2} \mathrm{SO}_{4}$ to determine nitrogen excretion to calculate the nonprotein respiratory exchange ratio

\section{Protocol 2: [1,2- ${ }^{13}$ C]acetate}

The acetate recovery in expired air was determined in a separate experiment of similar design during a 2-h baseline period and a 1-h period of exercise at $50 \% \mathrm{VO}_{2} \max$. After collection of a background breath sample, subjects received an iv priming dose of $0.085 \mathrm{mg} / \mathrm{kg}$ $\mathrm{NaH}^{13} \mathrm{CO}_{3}$. The stable isotope tracer $\left[1,2-{ }^{13} \mathrm{C}\right]$ acetate was continuously infused during the baseline period, and the rate of infusion was doubled at the start of the exercise period. The acetate tracer was dissolved into $0.9 \%$ saline to obtain a $3.46 \pm 0.02-\mathrm{mol} / \mathrm{L}$ solution. Acetate was infused at a rate of $0.064 \mu \mathrm{mol} / \mathrm{kg} \mathrm{BW} \cdot \mathrm{min}$ to obtain the same ${ }^{13} \mathrm{C}$ infusion rate per time unit as for the palmitate tracer. Breath samples were taken at similar time points as during the palmitate infusion.

\section{Biochemical methods}

Blood samples were collected in ethylenediamine tetraacetatecontaining tubes on ice and were immediately centrifuged at $4 \mathrm{C}$, and the plasma was put in liquid nitrogen until storage at $-80 \mathrm{C}$. Breath samples were analyzed for ${ }^{13} \mathrm{C} /{ }^{12} \mathrm{C}$ ratio by injecting $20 \mu \mathrm{L}$ of the gaseous head space into a gas chromatography (GC) continuous flow isotope ratio mass spectrometer (Finnigan MAT 252, Bremen, Germany). For determination of plasma palmitate and total FFA kinetics, FFA were extracted from plasma, isolated by thin layer chromatography, and derivatized to their methyl esters. Isotope enrichment of palmitate was determined by GC-isotope ratio mass spectrometry after on-line combustion of fatty acids to $\mathrm{CO}_{2}$ (Finnigan MAT 252). Palmitate concentrations were determined on an analytical GC with ion flame detection using heptadecanoic acid as internal standard, and on the average, it comprised $24 \pm 1 \%$ of the total FFA concentration. Total plasma FFA, glucose, glycerol, lactate, and infusate acetate concentrations were measured using standard enzymatic techniques automated on the Cobas Fara centrifugal analyzer at $340 \mathrm{~nm}$ (for FFA: FFA-C test kit, Wako Chemicals, Neuss, Germany; for glucose: Roche Unikit III, HoffmanLaRoche Inc., Basel, Switzerland; for glycerol and acetate: Roche Molecular Biochemicals, Mannheim, Germany). Plasma insulin was measured using a specific double antibody RIA for human insulin (Kabi Pharmacia, Uppsala, Sweden). Nitrogen concentrations in urine were measured using an elemental analyzer (type CN-O-Rapid; Heraeus, Hanau, Germany).

The muscle biopsies were homogenized in ice-cold Tris-ethylenediamine tetraacetate buffer at $\mathrm{pH}$ 7.4. The homogenates were subsequently sonicated four times for $15 \mathrm{~s}$ each time and centrifuged at $10,000 \times g$ for $2 \mathrm{~min}$ at $4 \mathrm{C}$ to remove cell debris. The tissue content of heart-type or muscle-type FABPc in skeletal muscle was measured by means of a newly developed enzyme-linked immunosorbent assay (Hycult Biotechnology, Uden, The Netherlands), using recombinant human FABP as standard (24). Citrate synthase was determined according to the method of Shepherd and Garland (25), whereas 3-hydroxyacyl-coenzyme A dehydrogenase was assayed according to the method of Bergmeyer (26).

\section{Calculations}

The metabolic rate was calculated from oxygen consumption and carbon dioxide production $\left(\mathrm{VO}_{2}\right.$ and $\left.\mathrm{VCO}_{2}\right)$ according to the equation of Weir (27). Carbohydrate and fat oxidation rates were calculated from $\mathrm{VO}_{2}, \mathrm{VCO}_{2}$, and urinary nitrogen excretion (28). Protein oxidation (calculated from nitrogen excretion) was assumed to be similar during the overnight fasted state and exercise. 


\section{Tracer calculations}

Fatty acid oxidation was calculated by converting the rate of triglyceride oxidation (grams per min) to its molar equivalent, with the assumption that the average molecular weight of triglyceride was 860 $\mathrm{g} / \mathrm{mol}$ and with a tripled molar rate of triglyceride oxidation because each molecule contains 3 mol fatty acids.

During the last $20 \mathrm{~min}$ of the baseline period (110 and $120 \mathrm{~min}$ ), a physiological and isotopic steady state was present, and therefore, Steele's equation for steady state was used to calculate the palmitate flux [rates of appearance or disappearance ( $\mathrm{Ra}$ or $\mathrm{Rd})]$, as reported previously (2). During the exercise period nonsteady state equations for the RaFFA and RdFFA were used (29).

The RaFFA was calculated by dividing the Ra of palmitate by the fractional contribution of palmitate to the total FFA concentration.

The fractional recovery of the acetate label in breath $\mathrm{CO}_{2}$ (acetate recovery factor) and the percentage of infused $\left[\mathrm{U}-{ }^{13} \mathrm{C}\right]$ palmitate oxidized were calculated as described previously (2).

Plasma-derived fatty acid oxidation (micromoles per min) was calculated as: oxidation $=$ RdFFA $\times \%$ of infused palmitate tracer oxidized.

The fatty acid oxidation from plasma triglycerides and intraorgan triglycerides (muscle and adipose tissue) was calculated as: sum of triglyceride - derived fatty acid oxidation $=$ total fatty acid oxidation plasma-derived fatty acid oxidation.

\section{Statistics}

Data are presented as the mean $\pm \mathrm{SE}$. Differences before and after diet were analyzed with Student's paired $t$ test. Statistical significance was set at $P<0.05$.

\section{Results}

Body composition, maximal aerobic capacity, and insulin sensitivity

As indicated in Table 1, there was a significant decrease in body weight, fat mass, and FFM as a result of the very low calorie diet. The 15.3-kg BW loss can be accounted for $78 \%$ by loss of fat mass and $22 \%$ by loss of FFM. The subjects were restudied after a 2-week weight-stable period (average weight change over this period, $-0.5 \pm 0.3$; range, -0.7 to $-0.2 \mathrm{~kg}$ ). Maximal aerobic capacity and maximal work load, as determined during the incremental cycling protocol, were not significantly different before compared with after the diet. Basal glucose and insulin concentrations significantly decreased after the diet. Also, there was a significant increase in insulin sensitivity as indicated by the increased insulin sensitivity index.

\section{Arterialized concentrations of circulating metabolites and hormones}

Glucose concentrations decreased during exercise both before and after the diet (Table 2). Glucose concentrations were lower after the diet compared with before under baseline conditions as well as during exercise. Basal FFA concentrations were not significantly different before and after the diet $(P=0.11)$. FFA concentrations did not change as a result of exercise before the diet, whereas exercise induced a significant increase in FFA concentrations after the diet. Basal glycerol concentrations decreased as a result of the diet, whereas glycerol concentrations during exercise were not different before and after the diet. Insulin concentrations decreased during exercise and were lower after compared with before the diet. Basal norepinephrine concentrations were lower after the diet, and norepinephrine concentrations during exercise were similar before and after the diet. Epinephrine concentrations increased during exercise, whereas epinephrine concentrations were not different before and after the diet.

\section{Whole body indirect calorimetry}

Whole body energy expenditure and total carbohydrate and fat oxidation reached a plateau after $40 \mathrm{~min}$ of exercise (data not shown). The mean values of the last $20 \mathrm{~min}$ of the baseline and exercise periods, expressed per FFM, are indicated in Fig. 1. Energy expenditure increased 4- to 5-fold as a result of exercise. There were no significant differences in
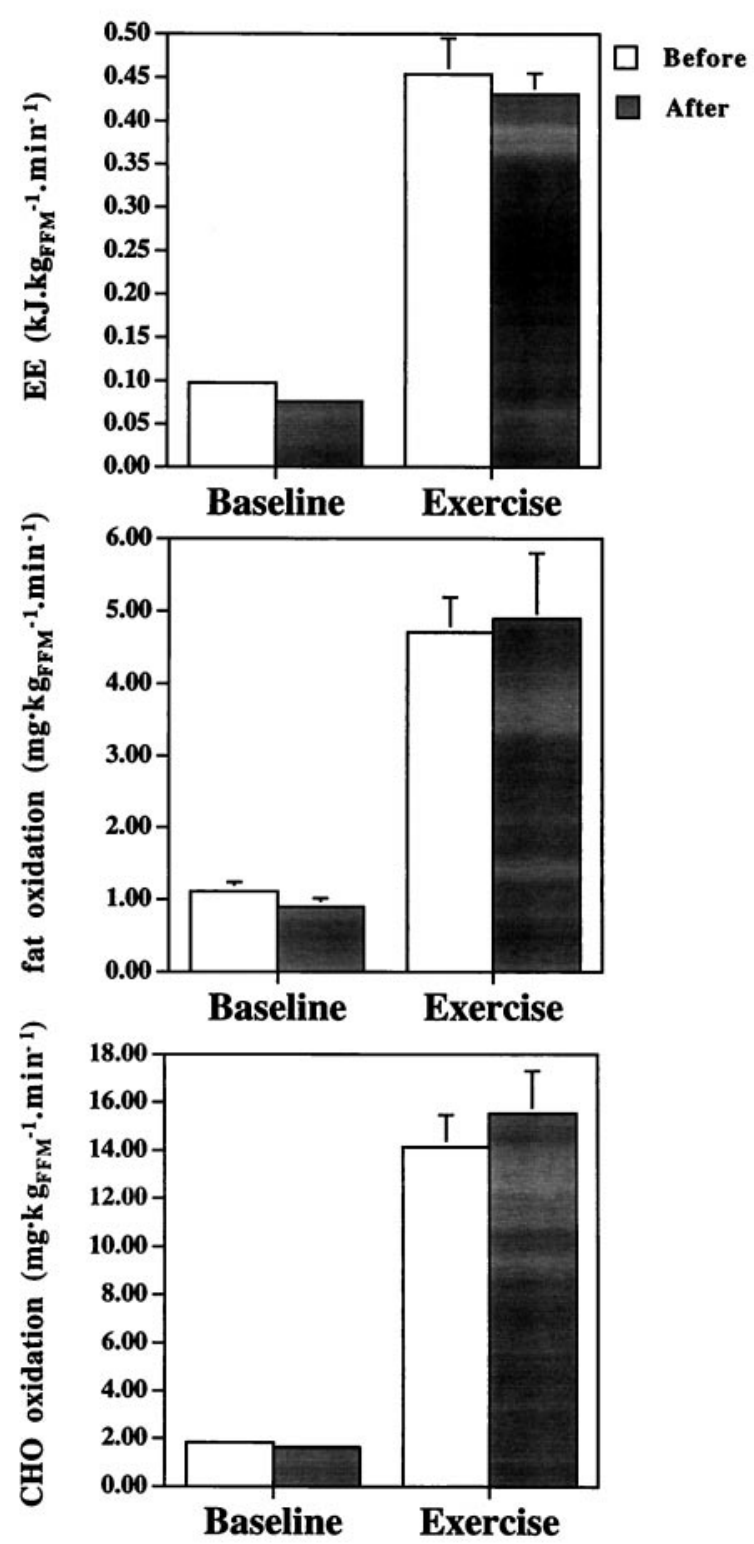

FIG. 1. Whole body energy expenditure (EE) and carbohydrate (CHO) and fat oxidation during baseline conditions and during moderate intensity exercise before and after weight reduction in obese type 2 diabetic subjects. For all variables, average exercise $v s$. baseline, $P<0.001$. 
energy expenditure or fat and carbohydrate oxidation before and after the diet throughout the experiment.

\section{Stable isotope infusion}

Acetate recovery increased gradually during baseline conditions and reached a plateau during exercise (Fig. 2). Acetate recovery during exercise was higher after compared with before the diet $(P<0.05)$. Baseline RaFFA and RdFFA decreased as a result of the diet, and these variables were similar during exercise before and after the diet (Fig. 3). Figure 4 shows the different components of fatty acid oxidation before and after the diet. Baseline and total fatty acid oxidation during exercise were not significantly different between the groups (Fig. 4, upper panel). The oxidation of plasma-derived FFA tended to decrease after the diet during baseline conditions $(P=0.10)$, whereas plasma-derived FFA oxidation during exercise was not different before and after the diet. Also, nonplasma-derived FFA oxidation was not significantly different before and after the diet.

\section{Muscle biopsies}

The concentration of FABPc tended to increase after the diet (before vs. after, $1.83 \pm 0.44$ vs. $2.08 \pm 0.34 \mathrm{mg} / \mathrm{g}$ total protein), but did not reach statistical significance. Also, the concentration of 3-hydroxyacyl-coenzyme A dehydrogenase (70.6 \pm 12.8 vs. $89 \pm 13 \mathrm{U} / g$ protein) and citrate synthase $(104 \pm 18$ vs. $111 \pm 14 \mathrm{U} / \mathrm{g}$ protein) were slightly higher after the diet, but were not statistically different compared with the prediet measurements.

There was a positive correlation between the amount of weight lost and the increase in FABPc (Fig. 5, upper panel). Also, the change in FABPc positively correlated to the change in baseline plasma-derived FFA oxidation (Fig. 5, lower panel).

\section{Discussion}

Impairments in fatty acid utilization are of importance in the etiology of type 2 diabetes mellitus. In a previous study

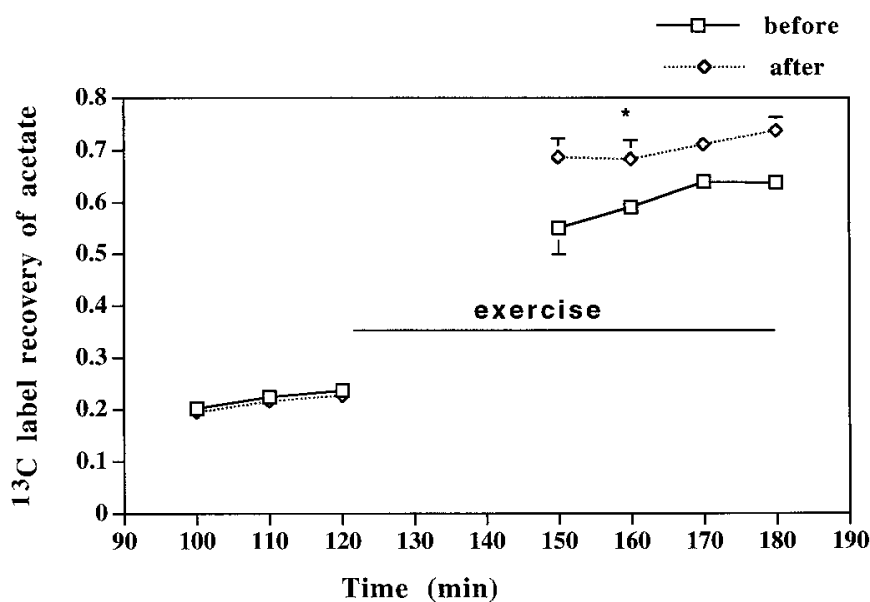

FIG. 2. Fractional ${ }^{13} \mathrm{C}$ label recovery of $\left[1,2-{ }^{13} \mathrm{C}\right]$ acetate during baseline conditions (90-120 min) and during moderate intensity exercise (121-160 $\mathrm{min}$ ) before and after weight reduction in obese type 2 diabetic subjects. Exercise, before $v s$. after: ${ }^{*}, P<0.05$. For average exercise (170 and $180 \mathrm{~min}) v s$. baseline $(120 \mathrm{~min}): P<0.001$.

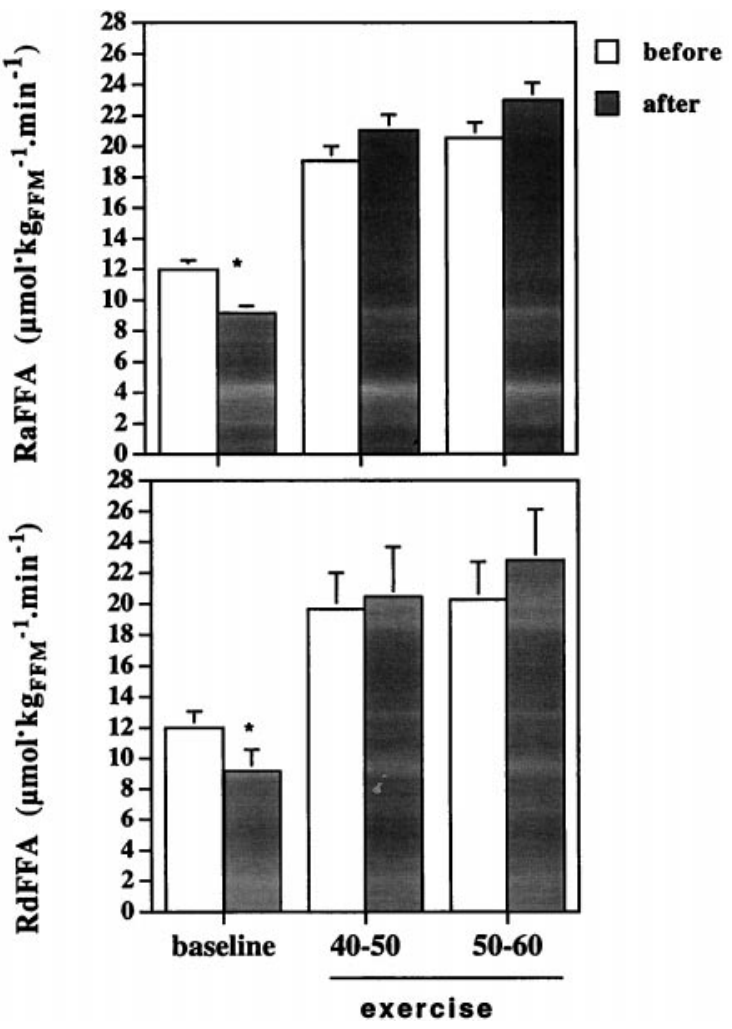

FIG. 3. RaFFA and RdFFA under baseline conditions and during moderate intensity exercise before and after weight reduction in obese type 2 diabetic subjects. Baseline, before $v s$. after: ${ }^{*}, P<0.05$. For all variables, average exercise $v s$. baseline: $P<0.001$.

we showed that plasma-derived fatty acid oxidation is lowered in type 2 diabetic subjects under baseline conditions as well as during physical exercise (3). The type 2 diabetic subjects of the previous study were restudied after weight reduction during weight stable conditions. Weight reduction resulted in a 15-kg body weight loss (percent body fat before vs. after, $37.4 \%$ vs. $31.2 \%$ ) and a considerable increase in insulin sensitivity.

\section{Plasma-derived FFA oxidation}

Both under baseline conditions as well as during physical exercise the lowered plasma-derived FFA oxidation did not significantly improve as a result of diet. These data suggest that these impairments in FFA utilization may be important factors leading to type 2 diabetes mellitus rather than merely resulting from the type 2 diabetic state. A lowered capacity to use fat during basal conditions has been implicated previously in the etiology of obesity and insulin resistance (1417). In this respect it is tempting to speculate that a primary defect in the ability to oxidize fat may cause an imbalance between muscle FFA uptake and oxidation and may thereby increase im triglyceride storage, which is strongly associated with insulin resistance (7). However, care has to be taken in interpreting the whole body plasma FFA oxidation during baseline conditions, because this reflects both skeletal muscle and liver FFA oxidation, the main fatty acid consumers during postabsorptive conditions (30). Thus, we cannot exclude that an improvement in baseline muscle FFA oxidation did 


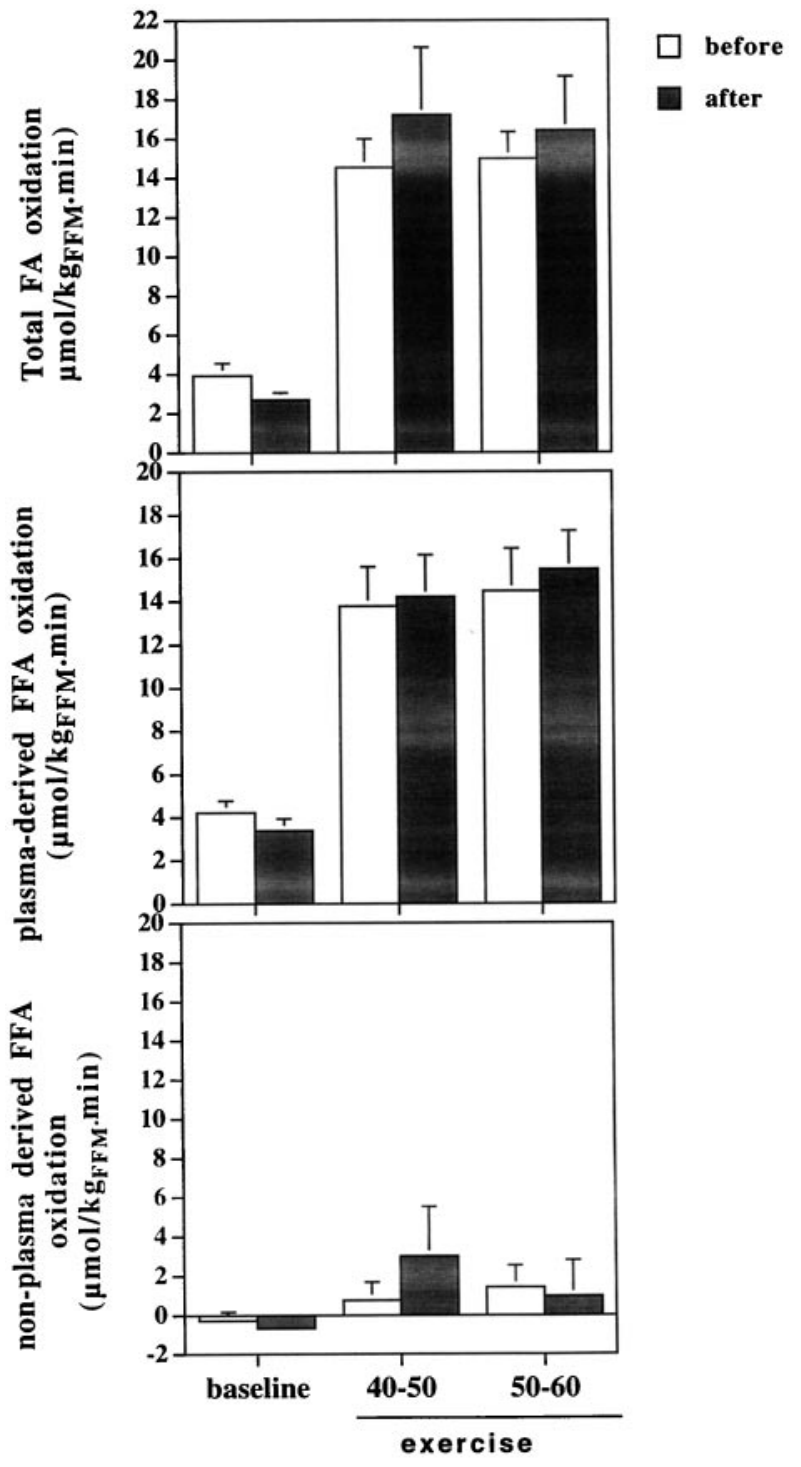

FIG. 4. Total fatty acid oxidation, plasma-derived fatty acid oxidation, and triglyceride-derived fatty acid oxidation before and after weight reduction in obese type 2 diabetic subjects. For total fatty acid oxidation and plasma-derived fatty acid oxidation: average exercise vs. baseline, $P<0.001$.

occur but was offset at the whole body level by a decrement in liver FFA oxidation. As skeletal muscle is largely responsible for the increase in fat oxidation during exercise (31), the present data show that the ability of skeletal muscle to oxidize plasma FFA during exercise does not significantly improve after the diet. Future studies have to show in what stage in the transition from the normal glucose tolerant to the type 2 diabetic state these disturbances develop.

\section{Underlying mechanisms}

One of the determining factors for muscle FFA utilization may be the FFA supply to muscle, which is an important driving force for fatty acid uptake (8). RaFFA and RdFFA were lowered in the type 2 diabetic subjects under baseline conditions as well as during exercise. As a result of the diet, baseline RaFFA and RdFFA decreased, whereas these pa-

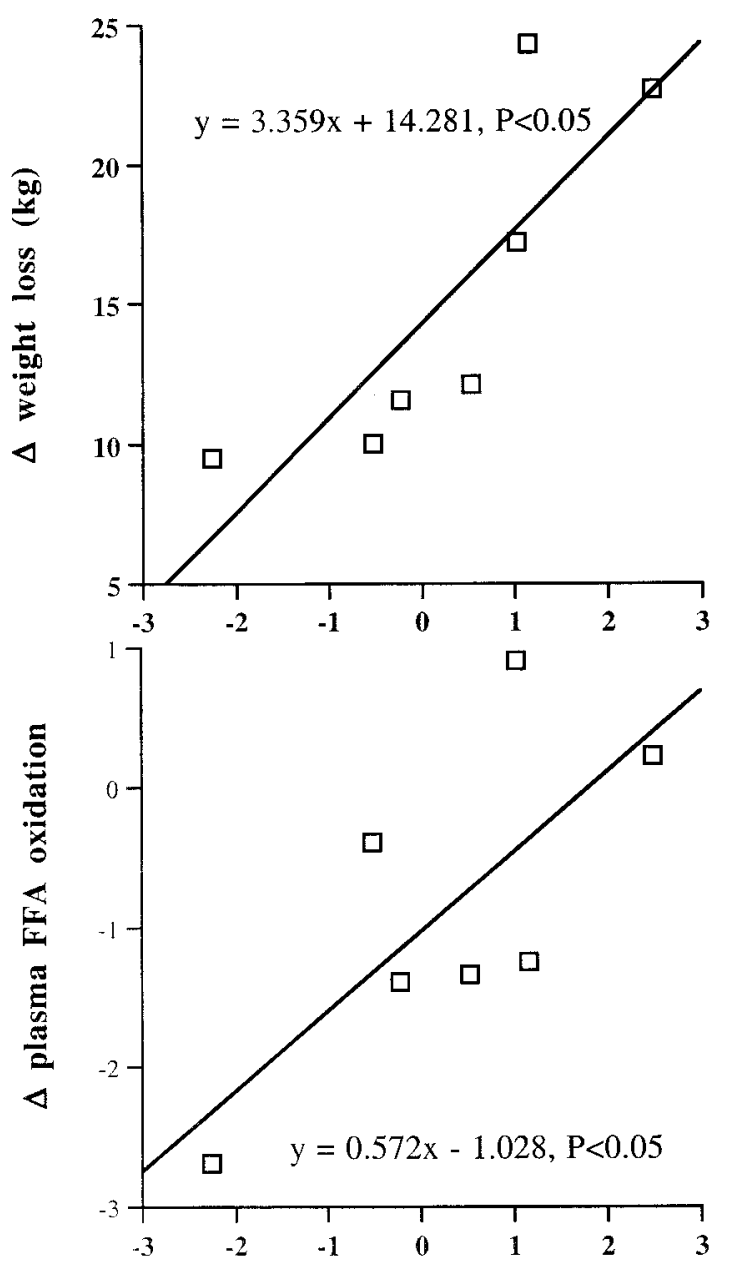

$\Delta$ Fabp (mg/g protein)

FIG. 5. Relationships between the increase in FABPc as result of weight reduction and body weight loss (upper panel) and baseline plasma-derived FFA oxidation (after vs. before) in obese type 2 diabetic subjects.

rameters did not change during exercise. Thus, the lowered FFA supply to muscle may provide an explanation for the diminished plasma-derived FFA oxidation in type 2 diabetic subjects.

Markers of skeletal muscle oxidative enzyme capacity and cytosolic fatty acid transport capacity did not significantly change after diet. However, there was a significant positive relationship between the amount of weight lost and the increase in FABPc. Also, the increase in FABPc was positively related to the change in baseline plasma-derived FFA oxidation (after $v s$. before). These data suggest that the ability to maintain or increase fatty acid transport capacity may be a determining factor in the success of a weight reduction program in type 2 diabetic subjects, as this would maintain or prevent the decrease in baseline plasma-derived FFA oxidation. Also, this correlation between increases in muscle FABPc and changes in baseline whole body FFA utilization (after vs. before) suggests that weight loss-induced changes in postabsorptive FFA utilization mainly occur in skeletal muscle. A role for FABPc in the physiological adaptations of 
fat metabolism after energy restriction has been suggested in obese women (32). Additionally, support for an important role for $\mathrm{FABPC}$ in impairments in fat utilization comes from a previous study (2), in which lowered muscle FABPc was observed in skeletal muscle of type 2 diabetic subjects.

\section{Conclusion}

In conclusion, the previously reported lowered postabsorptive and exercise-mediated plasma FFA oxidation in type 2 diabetic subjects did not significantly improve as a result of weight reduction, indicating that these disturbances may be important factors leading to the diabetic state rather than merely resulting from diabetes. We propose that a lowered FFA availability, as shown by the lowered RaFFA and RdFFA, may play an important role in this impaired FFA utilization. Furthermore, the present data suggest that the ability to maintain or increase muscle fatty acid transport capacity may be a determining factor in the success of a weight reduction program in type 2 diabetic subjects, as this would maintain or prevent the decrease in baseline plasmaderived FFA oxidation.

\section{References}

1. Kelley DE, Simoneau J. 1994 Impaired free fatty acid utilization by skeletal muscle in non-insulin dependent diabetes mellitus. J Clin Invest. 94:2349-2356.

2. Blaak EE, Wagenmakers AJM, Glatz JFC, et al. 2000 Plasma free fatty acid utilization and fatty acid binding protein content are diminished in type 2 diabetic muscle. Am J Physiol Endocrinol Metab. 279:E146-E154.

3. Blaak EE, van Aggel-Leijssen DPC, Wagenmakers AJM, Saris WHM, van Baak MA. 2000 Impaired oxidation of plasma-derived fatty acids in type 2 diabetic subjects during moderate intensity exercise. Diabetes, 49:2102-2107.

4. Svedberg J, Björntorp P, Smith U, Lönnroth P. 1990 Free-fatty acid inhibition of insulin binding, degradation, and action in isolated rat hepatocytes. Diabetes. 39:570-574

5. Lewis GF, Vranic M, Harley P, Giacca A. 1997 Fatty acids mediate the acute extrahepatic effects on hepatic glucose output. Diabetes. 46:111-1119.

6. Frayn KN, Williams CM, Arner P. 1996 Are increased plasma non-esterified fatty acid concentrations a risk marker for coronary heart disease and other chronic diseases? Clin Sci. 90:243-253.

7. Perseghin G, Scifo P, De Cobelli F, et al. 1999 Intramyocellular triglyceride content is a determinant of in vivo insulin resistance in humans. Diabetes. 48:1600-1606.

8. Van der Vusse GJ, Reneman RS. 1996 Lipid metabolism in muscle. In: Handbook of physiology, sect 12. Oxford: Oxford University Press; 952-994.

9. Dyck DJ, Peters SJ, Glatz J, et al. 1997 Funtional differences in lipid metabolism in resting skeletal muscle of various fibre types. Am J Physiol. 272:E340-E351.

10. Simoneau JA, Veerkamp JH, Turcotte LP, Kelley DE. 1999 Markers of the capacity to utilize fatty acids in human skeletal muscle. FASEB J. 13:2051-2060.
11. Luiken JJFP, Schaap FG, van Nieuwenhoven FA, van der Vusse GJ, Bonen A, Glatz JFC. Cellular fatty acid transport in heart and skeletal muscle as facilitated by proteins. Lipids. 34:S169-S175.

12. Colberg SR, Simoneau J, Thaete FL, Kelley DE. 1994 Skeletal muscle utilization of FFA in women with visceral obesity. J Clin Invest. 95:1846-1853.

13. Blaak EE, van Baak MA, Kemerink GJ, Pakbiers MTW, Heidendal GAK, Saris WHM. $1994 \beta$-Adrenergic stimulation of whole body energy expenditure and skeletal muscle metabolism in lean and obese men. Am J Physiol. 267:E306-E315.

14. Blaak EE, van Baak MA, Kemerink GJ, Pakbiers MTW, Heidendal GAK, Saris WHM. $1994 \beta$ Adrenergic stimulation of whole body energy expenditure and skeletal muscle metabolism in relation to weight reduction in obese men. Am J Physiol. 267:E316-E322.

15. Kelley BE, Goodpaster B, Wing RR, Simoneau JA. 1999 Skeletal muscle fatty acid metabolism in associateion with insulin resistance, obesity and weight loss. Am J Physiol. 40:E1130-E1141.

16. Zurlo F, Lillioja S, Esposito-Del Puente A, et al. 1990 Low ratio of fat to carbohydrate oxidation as predictor of weight gain: study of $24-\mathrm{h} R \mathrm{R}$. Am J Physiol. 259:E650-E657.

17. Ranneries C, Bülow J, Buemann B, Christensen NJ, Madsen J, Astrup A. 1998 Fat metabolism in formerly obese women. Am J Physiol. 274:E155-E161.

18. Sidossis LS, Coggan AR, Castaldelli A, Wolfe RR. 1995 A new correction factor for the use in tracer estimations of plasma fatty acid oxidation. Am J Physiol. 269:E649-E656.

19. Sidossis LS, Coggan AR, Gastaldelli A, Wolfe RR. 1995 Pathway of free fatty acid oxidation in human subjects. J Clin Invest. 95:278-284.

20. Schrauwen $P$, Blaak EE, van Aggel-Leijssen, Borghouts LB, Wagenmakers AJM. 2000 Determination of the acetate recovery factor: implications for estimations of $\left[{ }^{13} \mathrm{C}\right]$ substrate oxidation. Clin Sci. 98:587-592.

21. Siri WE. 1956 The gross composition of the body. Adv Biol Med Physiol. 4:239-280.

22. Bonora E, Moghetti P, Zancanaro C, et al. Estimates of in vivo insulin action in man: comparison of the insulin tolerance tests with euglycemic and hyperglycemic clamp studies. J Clin Endocrinol Metab. 68:374-378.

23. Evans WJ, Phinney SD, Young VR. 1982 Suction applied to a muscle biopsy maximizes sample size. Med Sci Sports Exer. 14:101-102.

24. Wodzig KWH, Pelsers MMAL, van der Vusse GJ, Roos W, Glatz JFC. 1997 One-step enzyme linked immunosorbent assay (ELISA) for plasma fatty acidbinding protein. Ann Clin Biochem. 34:263-268.

25. Shepherd D, Garland PB. 1969 Citrate synthase from the rat liver. Methods Enzymol. 13:11-16.

26. Bergmeyer HU. 1974 Methods of enzymatic analysis. New York: Academic Press; vol 1:474-476, 480-482.

27. Weir JB. 1949 New methods for calculating metabolic rate with special reference to protein metabolism. J Physiol. 109:1-9.

28. Frayn KN. 1983 Calculation of substrate oxidation rates in vivo from gaseous exchange. J Appl Physiol. 55:628-634

29. Steele R. 1959 Influence of glucose loading and of injected insulin on hepatic glucose output. Ann NY Acad Sci. 82:420-430.

30. Elia M. 1991 The inter-organ flux of substrates in fed and fasted man, as indicated by arterio-venous balance studies. Nutr Res Rev 4:3-31.

31. Wolfe RR. 1967 Fat metabolism in exercise. In: Skeletal muscle metabolism in exercise and diabetes. New York: Plenum Press; 147-156.

32. Kempen KPG, Saris WHM, Kuipers H, Glatz JFC, van der Vusse GJ. 1998 Skeletal muscle metabolic characterics before and after energy restriction in human obesity: fibre type, enzymatic $\beta$-oxidative capacity and fatty acidbinding content. Eur J Clin Invest. 28:1030-1037. 